\title{
Syndrome of polydactyly, cleft lip/palate or lingual lump, and psychomotor retardation in endogamic gypsies
}

\author{
V VÁRADI, L SZABÓ, AND Z PAPP
}

From the Departments of Paediatrics, Stomatology, Obstetrics, and Gynaecology, University Medical School, Debrecen, Hungary

SUMMARY Six children in an inbred isolate (a gypsy colony) were found to have a syndrome of reduplication of the big toes, supernumerary fingers on the hands, cleft lip/palate or lingual noduie, and somatic and psychomotor retardation. Other features sometimes present were absence of olfactory bulbs and tracts, cryptorchidism, inguinal hernia, and congenital heart disease. The disorder has overlapping features with several previously delineated syndromes, but is most similar to the anomalies of trisomy 13 Mand ohr's syndrome. Our patients had a normal karyotype. The mode of inheritance of this lethal genetic syndrome is probably autosomal recessive.

Since 1960 many cases of trisomy 13 syndrome have been reported, and its characteristic features are well defined. ${ }^{1-4}$ There are also reports of similar phenotypes with normal karyotype. ${ }^{56}$ We have recently studied a male gypsy child with a combination of malformations similar to those of Patau's syndrome and a normal male complement of 46 chromosomes in all cells cultured from peripheral blood. In this gypsy colony a further five cases have been found with similar features. The six cases are of interest from the nosological point of view and merit a detailed description.

\section{Case report}

Near Debrecen (the largest city in eastern Hungary) there are two large gypsy colonies $30 \mathrm{~km}$ from each Received for publication 4 June 1979 other in Hajdúhadház and Hosszúpályi with about 800 and 1500 residents, respectively. Within gypsy groups many children are born as a result of extramarital relationships, and because of the difficulties of tracing connections it has been possible to draw the pedigrees for only three generations (fig $1,2,3$ ). The large number of admitted extramarital connections and the small number of surnames (only six) reveal a high degree of endogamy in these colonies. Hence, although consanguinity between families A, B, and C is not admitted, it is probable that it exists. Details of the six affected children are presented in the table, and additional features of the proband are given below.

CASE 1: F-K, III.22, FAMILY A

The parents are healthy and normally developed. The mother was aged 20 years and the father 21

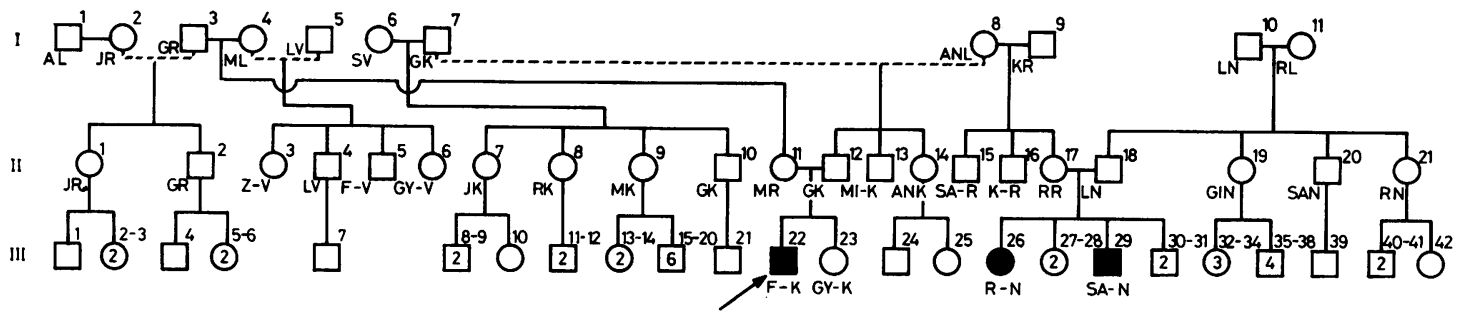

FIG 1 Pedigree of family A, resident in Hajdúhadház. The last letter beside each symbol is the initial of the urname. 
TABLE Occurrence of features in 6 affected children

\begin{tabular}{|c|c|c|c|c|c|c|}
\hline & Case $1(F-K)$ & Case $2(R-N)$ & Case $3(S A-N)$ & Case $4(A R-R)$ & Case $5(K-R)$ & Case $6(I-L)$ \\
\hline Pedigree No & $\begin{array}{l}\text { A/III.22 } \\
\text { (Cousin of R-N } \\
\text { and SA-N) }\end{array}$ & $\begin{array}{l}\text { A/III.26 } \\
\text { (Cousin of F-K } \\
\text { and sister of } \\
\text { SA-N) }\end{array}$ & $\begin{array}{l}\text { A/III.29 } \\
\text { (Cousin of F-K } \\
\text { and brother of } \\
\text { R-N) }\end{array}$ & $\begin{array}{l}\text { B/III.15 } \\
\text { (Sib of K-R) }\end{array}$ & $\begin{array}{l}\text { B/III.16 } \\
\text { (Sib of AR-R) }\end{array}$ & C/III.33 \\
\hline Sex & $\mathbf{M}$ & $\mathbf{F}$ & $\mathbf{M}$ & $\mathbf{F}$ & $\mathbf{M}$ & $\mathbf{F}$ \\
\hline $\begin{array}{l}\text { Age at death } \\
\text { Polydactyly (on each hand }\end{array}$ & $3 \mathrm{yr}$ & $6 \mathrm{yr}$ & $1 \mathrm{dy}$ & $1 \mathrm{mth}$ & 1 wk & $2 \mathrm{wk}$ \\
\hline and foot) & + & $t^{*}$ & + & + & + & + \\
\hline Cleft lip & + & - & - & - & - & + \\
\hline Cleft palate & + & - & + & + & - & + \\
\hline Lingual tumour & - & + & - & - & $+\dagger$ & - \\
\hline Intrauterine retardation & + & - & + & + & + & + \\
\hline Postnatal somatic retardation & + & + & & + & & + \\
\hline $\begin{array}{l}\text { Psychomotor retardation } \\
\text { Absence of olfactory bulbs }\end{array}$ & + & + & & + & & \\
\hline $\begin{array}{l}\text { Absence of olfactory bulbs } \\
\text { and tracts }\end{array}$ & + & ? & ? & $?$ & + & $?$ \\
\hline Cryptorchidism & + & & + & & + & \\
\hline Inguinal hernia & + & - & + & - & + & - \\
\hline Karyotype & $46, X Y$ & $46, X X$ & $?$ & $?$ & $46, X Y$ & $?$ \\
\hline
\end{tabular}

? not examined.

*The third metacarpal of each hand was bifurcate, with one finger arising from each half (fig 7).

$\dagger$ There was a lingual nodule the size of a rice grain, which was found histologically to contain lobated fat and normal mucous salivary gland $T$ tissues (fig 8). In other respects the tongue was normal.

years at the child's birth. The mother gave no reliable history of illness or of having taken drugs during this, her first, pregnancy. Labour and delivery were normal and the child was born at term, birthweight $2300 \mathrm{~g}$ and length $47 \mathrm{~cm}$. Most of the malformations were noted at birth (fig 4, 5). He had a right-sided cleft lip and palate, seven fingers on the left hand, six on the right hand, and six toes on each foot. The extra big toes were symmetrically placed. Additional features were elongated skull, ocular hypertelorism, epicanthic folds, strabismus, low-set malformed ears, equinovarus feet, inguinal hernia, and undescended testes. The karyotype on $\omega$ peripheral lymphocyte culture was normal, 46,XY.? The mother's karyotype was $46, \mathrm{XX}$.

He had failed to thrive from birth, had continuous $ळ$ high temperature, and was retarded both physically ${ }_{-}^{+}$ and mentally, with only minimal vegetative functions. He had not been observed to have seizures. No $\frac{\vec{D}}{\mathrm{D}}$ protective or neonatal reflexes could be elicited. $\stackrel{?}{\stackrel{P}{\circ}}$ Psychomotor development was clearly retarded and $\stackrel{\mathbb{Q}}{\varrho}$ at the age of 12 months corresponded to that of a $4{ }^{\circ}$ 


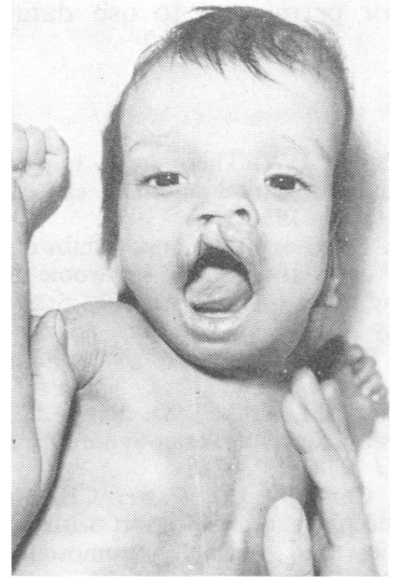

FIG 4 Case $1(F-K)$. Right-sided cleft lip and palate. Minor aberrations of face.

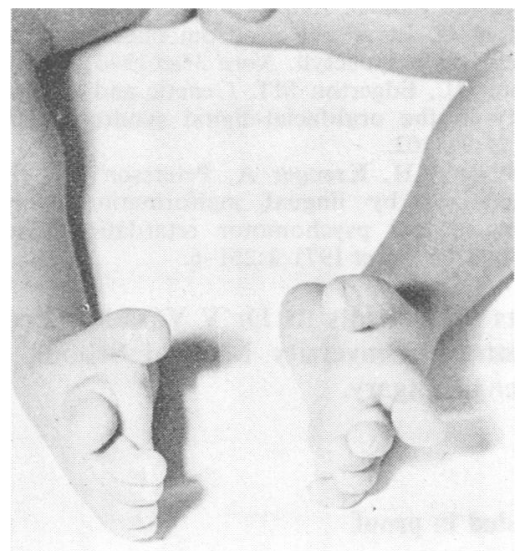

FIG 5 Case $1(F-K)$. Reduplication of the big toes.

month-old child. He showed hypotrophy of the muscles of the trunk, shoulders, and upper arms, and general pronounced muscle hypotonia. Gross motor development was characterised by reduced head balance and mobility of the arms and legs. He could not speak and could neither sit up nor walk. His eyes did not follow objects which passed in his visual field.

At his death, aged 3 years, he weighed $5400 \mathrm{~g}$ with a length of $73 \mathrm{~cm}$, fronto-occipital diameter of $16 \mathrm{~cm}$, and biparietal diameter of $10 \mathrm{~cm}$. The teeth were irregular with hypoplastic enamel, and some were missing. The direct cause of death was lung oedema, resulting from insufficiency of the left ventricle.

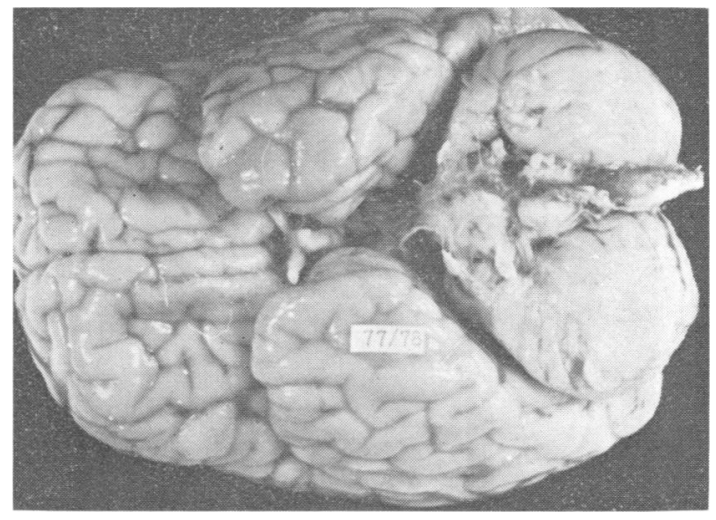

FIG 6 Case $1(F-K)$. Ventral view of brain stem and cerebellum. Note absence of olfactory bulbs and tracts.

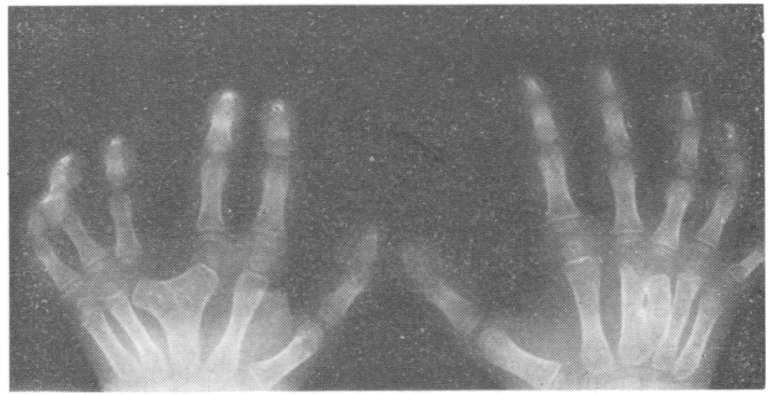

FIG 7 Case $2(R-N)$. X-ray of polydactyl hands at the age of 5 .

The necropsy uncovered further malformations including congenital heart disease (aortic stenosis), cholangiodysplasia, absent olfactory bulbs and tracts, absent fossa interpeduncularis, and absent vermis in the brain (fig 6).

\section{Discussion}

The full complement of defects observed in these six children is unusual, although a number of them are characteristic of previously described syndromes. The features are most similar to the anomalies which have been found in trisomy $13^{2}$ and in Mohr's syndrome. ${ }^{7} 8$ The anomalies which the proband had in common with the majority of established cases of trisomy 13 were harelip and cleft palate, feeding difficulty, failure to thrive, developmental and psychomotor retardation, polydactyly, absence of olfactory nerves, cardiac defect, ocular hypertelorism, epicanthic folds, strabismus, low-set malformed ears, equinovarus feet, undescended testes, and inguinal hernia. In all six cases a malformation 


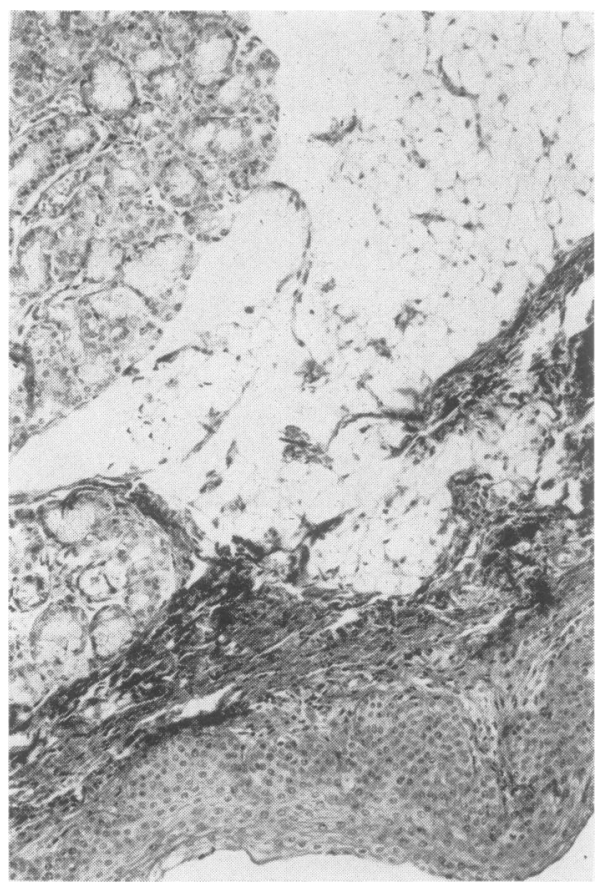

FIG 8 Case $5(K-R)$. Histological picture of nodule in the tongue. Note fat and salivary gland tissues.

of the mouth was observed, either a cleft lip/palate (four cases), or a lingual nodule (two cases). Lingual lumps are associated with malformations of structures derived from the first branchial arch anlage, cleft lip, cleft palate, and dental anomalies, in Mohr's syndrome. ${ }^{910}$ However, they are not found in trisomy 13, and we have found no reported cases of Mohr's syndrome associated with absence of olfactory bulbs and tracts, which is a characteristic feature of Patau's syndrome.

A survey of published reports failed to reveal a report of familial occurrence with a similar combination of malformations to our case. We think that the findings in the proband and in other members of the gypsy families represent a nosological entity. The fact that the syndrome is confined to three families makes it unlikely that an environmental factor is responsible. $G$ banding carried out in three cases showed no translocation or other structural rearrangement in any of the chromosomes, including autosome 13. The gene is lethal, with four of six dying within 2 weeks, one at 3 years, and one at 6 years. Examination of the pedigrees $\mathrm{A}, \mathrm{B}$, and $\mathrm{C}$ suggests that the mode of inheritance is most probably autosomal recessive and is unlikely to result from a dominant gene with incomplete penetrance.
We are grateful to Drs Sz Szakáll, E Martini, and $\mathrm{P}$ Molnár for permission to use data from their patients.

\section{References}

1 Patau K, Smith DW, Therman E, Inhorn SL, Wagner HP. Multiple congenital anomaly caused by an extra autosome. Lancet 1960;1:790-3.

2 Taylor AI. Autosomal trisomy syndromes: a detailed study of 27 cases of Edwards' syndrome and 27 cases of Patau's syndrome. J Med Genet 1968;5:227-52.

3 de Grouchy J, Turleau C. Atlas des maladies chromosomiques. Paris: Expansion Scientifique Francaise, 1977.

4 Pap Z, Buczkó I, Szakáll Sz, Papp Z. Hochgradiger Mikrophthalmus beim Patau-Syndrom. Klin Monatsbl Augenheilkd 1978;173:342-7.

5 Bishop K, Connolly JM, Carter CH, Carpenter DG. Holoprosencephaly. A case report with no extracranial $=$ abnormalities and normal chromosome count and 6 karyotype. J Pediatr 1964;65:406-14.

6 Marshall R, Newnham RE, Rawstron JR, Ellis JR, Stevens LJ. Features of 13-15 trisomy syndrome with normal karyotype. Lancet 1964;1:556.

7 Mohr OL. A hereditary sublethal syndrome in man. Skr Norske Vidensk Akad Mat Nat Kl 1941;14:3-17.

${ }^{8}$ Claussen O. Et arvelig syndrom omfattende tungemisdannelse og polydactyli. Nord Med 1946;30:1147-51.

Rimoin DL, Edgerton MT. Genetic and clinical heterogeneity in the oral-facial-digital syndromes. $J$ Pediatr 1967;71:94-102.

10 Gustavson KH, Kreuger A, Petersson PO. Syndrome characterized by lingual malformation, polydactyly, tachypnea, and psychomotor retardation (Mohr syndrome). Clin Genet $1971 ; 2: 261-6$.

Requests for reprints to Dr V Váradi, Department of Pediatrics, University Medical School, H-4012 Debrecen, Hungary.

\section{Note added in proof}

Since submitting our manuscript we have confirmed a further case of this syndrome from the same gypsy colony. The mother of the patient has had a total of 11 children to date including, in addition to the patient, three who died within the first 3 months of life and seven who are alive and 0 healthy. The patient, who is now 3 years old, and is being cared for in a home for mentally retarded children, was small for dates and has polydactyly on each hand and foot, cleft lip and palate, and somatic and psychomotor retardation. The karyotype is normal. According to the parents one of the children that died also had extra fingers and toes and a hare lip.

This syndrome is detectable by fetoscopy and therefore provides an example of a type of mental retardation that is potentially preventable by selective abortion. 